\title{
PROFIL KREATIVITAS MAHASISWA DALAM MEMECAHKAN MASALAH GEOMETRI PADA MATERI SISTEM KOORDINAT RUANG
}

\author{
Tri Andari ${ }^{1}$, Restu Lusiana ${ }^{2}$ \\ ${ }^{1,2}$ Prodi Pendidikan Matematika, IKIP PGRI Madiun \\ ${ }^{1}$ Email: triandari229@yahoo.com, \\ ${ }^{2}$ Email: lucie.azurra@yahoo.com
}

\begin{abstract}
Abstrak
Penelitian ini bertujuan mengetahui profil kreativitas mahasiswa dalam memecahkan masalah Geometri pada materi sistem koordinat ruang. Subyek dalam penelitian ini adalah mahasiswa program studi pendidikan matematika semeter III IKIP PGRI Madiun. Jenis penelitian yang digunakan adalah penelitian kualitatif. Teknik pengumpulan data dalam penelitian ini diperoleh berdasarkan hasil tes dan wawancara. Teknik analisis data terdiri dari tiga alur yaitu reduksi data, penyajian data, dan penarikan kesimpulan atau verifikasi. Kesimpulan dari penelitian ini adalah (1) Mahasiswa dengan kriteria kemampuan tinggi berkecenderungan untuk memiliki profil kreativitas terhadap hasil belajar yang baik dalam memecahkan masalah Geometri pada materi sistem koordinat ruang. (2) Mahasiswa dengan kriteria kemampuan sedang berkecenderungan untuk memiliki profil kreativitas terhadap hasil belajar yang cukup baik dalam memecahkan masalah Geometri pada materi sistem koordinat ruang. (3) Mahasiswa dengan kriteria kemampuan rendah berkecenderungan untuk memiliki profil kretivitas yang kurang baik dalam memecahkan masalah Geometri pada materi sistem koordinat ruang.
\end{abstract}

Kata Kunci: Kreativitas, Pemecahan Masalah, Geometri, Sisitem Koordinat Ruang

\section{PENDAHULUAN}

Pembelajaran merupakan kegiatan penting yang harus dilakukan sebagai upaya untuk meningkatkan pemahaman terhadap suatu materi perkuliahanserta mengembangkan kreativitas berpikir bagi setiap mahasiswa. Dalam keseluruhan proses pendidikan, kegiatan pembelajaran merupakan kegiatan paling pokok. Hal ini berarti bahwa berhasil tidaknya pencapaian tujuan pendidikan banyak bergantung kepada bagaimana proses pembelajaran dirancang dan dijalankan secara profesional. Pembelajaran merupakan proses komunikasi dua arah, mengajar dilakukan oleh pihak guru sebagai pendidik, sedangkan belajar dilakukan oleh peserta didik atau mahasiswa. Peranan dosen bukan semata-mata memberikan informasi melainkan juga mengarah dan memberi fasilitas belajar (directing and facilitating the learning) agar proses belajar lebih memadai. 
Keberhasilan belajar sangat didukung oleh kondisi lingkungan belajar yang kondusif dan yang menyenangkan, positif serta kreatif untuk belajar. Tetapi setiap individu siswa memiliki tingkat kemampuan berpikir yang berbeda-beda dan tidak ada yang sama persis. Jika kemampuan berpikir kreatif tidak dipupuk dan dikembangkan secara maksimal, maka kemampuan berpikir tidak akan bertambah, bahkan mungkin akan berkurang. Agar kemampuan berpikir kreatif siswa dapat optimal. Kemampuan tersebut harus terus diasah dengan menambahkan wawasan pengetahuan yang lebih luas.

Upaya untuk meningkatkan kemampuan berpikir kreatif siswa tidak terlepas dari adanya interaksi yang baik antara mahasiswa dan dosenu dalam proses pembelajaran. Dosen harus memikirkan bagaimana cara terjadinya interaksi yang aktif dimana tercipta suatu lingkungan belajar yang dapat menguatkan kemampuan berpikir kreatif mahasiswa. Dalam hal ini dosen hanya bertindak sebagai fasilitator bukan sebagai sumber informasi primer. Oleh karena itu, pola berpikir tersebut perlu dikembangkan dan kemudian diaplikasikan dalam bentuk pemecahan masalah.

Pentingnya kreativitas juga tertera dalam Sistem Pendidikan Nasional No.20
Tahun 2003 yang mengemukakan bahwa melalui pendidikan diharapkan dapat mengembangkan potensi peserta didik agar menjadi manusia yang bertakwa, berakhlak mulia, cakap, kreatif juga mandiri. Namun kenyataan yang ada adalah hasil belajar pada mata kuliah Geometri masih tergolong rendah antara lain ditunjukkan antara rendahnya hasil ujian akhir semester (UAS) yang umumnya di bawah nilai 70 .

Materi sistem koordinat ruang merupakan materi yang sebetulnya tidak sulit karena banyak ditemui dalam kehidupan sehari-hari, tetapi banyak mahasiswa yang merasa kesulitan. Selain itu, mayoritas mahasiswa juga mengeluhkan bahwa pada mata kuliah geometri banyak sudut-sudut dan hafalan rumus-rumus untuk memecahkan masalah soal Geometri.

Banyak faktor yang mungkin menyebabkan rendahnya kreativitas siswa dalam pelajaran matematika. Faktor-faktor tersebut dapat berupa faktor kreativitas siswa, minat, motivasi dan genetika. Faktor lainnya mungkin ditimbulkan dari guru, alat belajar, kondisi lingkungan keluarga ataupun teman. Akan tetapi, peran orang tua sangatlah penting dalam meningkatkan kemampuan kreativitas siswa. Jadi, siswa tidak hanya bergantung pada bimbingan belajar, namun juga harus belajar di 
rumah dan lebih memperhatikan penjelasan guru di sekolah. Berdasarkan uraian di atas, maka peneliti mengangap perlu untuk melakukan untuk mengetahui profil kreativitas mahasiswa dalam memecahkan masalah Geometri pada materi sistem koordinat ruang.

\section{METODE PENELITIAN}

Penelitian ini menggunakan jenis pendekatan deskriptif kualitatif karena merupakan penelitian yang ditanya dalam bentuk verbal dan dianalisis tanpa menggunakan teknik statistik. Penelitian ini bertujuan untuk mengetahui gambaran atau profil kreativitas terhadap hasil belajar dalam menyelesaikan masalah sehingga dalam penelitian ini pengambilan data dilakukan dengan metode tes, wawancara, observasi dan angket sehingga data yang diperoleh data nonstatistik dan analisis data yang diperoleh berupa kata-kata dan bukan angka.

Menurut Gay dan Airasian (dalam Emzir, 2011: 37) observasi, wawancara, dokumen pribadi dan resmi, foto, rekaman, gambar dan percakapan informal semua merupakan sumber data kualitatif. Sumber yang paling umum digunakan adalah observasi, wawancara dan dokumen. Berdasarkan sumber data pada definisi di atas, maka dalam penelitian ini sumber data didapat dari hasil tes, dan wawancara yang dilakukan kepada mahasiswa secara langsung dan terperinci.

Subyek dalam penelitian ini adalah mahasiswa studi pendidikan matematika semeter III IKIP PGRI Madiun yang terdiri dari 6 orang mahasiswa yang dibagi dalam tiga kategori yaitu, 2 orang mahasiswa dengan kategori kemampuan tinggi, 2 orang mahasiswa dengan kategori kemampuan sedang, dan 2 orang mahasiswa dengan kategori kemampuan rendah. Berikut ini adalah kriteria masing-masing kategori kemampuan berdasarkan nilai mahasiswa Ujian tengah semester mata kuliah Geometri :

a. Jika nilai mahasiswa $\geq 80$, maka dikategorikan tinggi

b. Jika nilai mahasiswa $65-80$, maka dikategorikan sedang

c. Jika nilai mahasiswa $\leq 65$, maka dikategorikan rendah

Baik buruknya suatu penelitian sebagian tergantung kepada teknik-teknik pengumpulan datanya. Pengumpulan data dalam penelitian umum bermaksud memperoleh bahan-bahan yang relevan, akurat dan reliabel.Menurut Sugiyono (2007: 224) Teknik pengumpulan data merupakan langkah yang paling utama dalam penelitian, karena tujuan utama dari penelitian adalah mendapatkan data. Tanpa mengetahui teknik pengumpulan data, maka peneliti tidak akan 
mendapatkan data yang memenuhi standar data yang ditetapkan.

Secara umum terdapat empat macam tehnik pengumpulan data, yaitu observasi, tes, dokumentasi dan wawancara. Namun peneliti disini menggunakan dua teknik yaitu tes dan wawancara.

\section{Metode Tes}

Menurut Anas Sudijono (2009: 67) tes adalah cara atau prosedur dalam rangka pengukuran dan penilaian di bidang pendidikan, yang berbentuk pemberian tugas atau serangkaian tugas berupa pertanyaanpertanyaan oleh testee, sehingga dapat dihasilkan nilai yang melambangkan tingkah laku atau prestasi testee, nilai mana dapat dibandingkan dengan nilai standar tertentu. Maka dalam penelitian ini, peneliti menggunakan metode tes yang digunakan untuk mengetahui kreativitas mahasiswa dalam memecahkan masalah Geometri .

2. Metode Wawancara

Menurut Suharsimi Arikunto (2012: 44) berpendapat bahwa "wawancara adalah suatu metode atau cara yang digunakan untuk mendapatkan jawaban dari responden dengan cara tanya-jawab sepihak".

Metode wawancara yang dilakukan peneliti adalah wawancara terbuka, yaitu wawancara yang dilakukan peneliti dengan mengajukan pertanyaan-pertanyaan yang tidak dibatasi jawabannya, artinya pertanyaan-pertanyaan yang mengundang jawaban terbuka. Tujuan wawancara ini adalah untuk mengetahui gambaran kreativitas mahasiswa dalam menyelesaikan soal.

Uji keabsahan dapat dilakukan dengan triangulasi pendekatan dengan kemungkinan melakukan terobosan metodologis terhadap masalah-masalah tertentu yang kemungkinan dapat dilakukan. Menurut Burhan Bungin (2007: 257) triangulasi untuk menguji keabsahan data dibagi menjadi 4, yaitu :

1. Triangulasi Kejujuran Peneliti Cara ini dilakukan untuk menguji kejujuran, subjektivitas dan kemampuan merekam data oleh peneliti di lapangan.

2. Triangulasi dengan Sumber Data

$$
\text { Dilakukan dengan }
$$

membandingkan dan mengecek baik derajat kepercayaan suatu informasi yang diperoleh melalui waktu dan cara yang berbeda.

3. Triangulasi dengan Metode

$$
\text { Ini dilakukan untuk }
$$
melakukan pengecekan terhadap penggunaan metode pengumpulan data, apakah informasi yang didapat 
dengan metode interview sama dengan metode observasi atau sebaliknya. Apabila berbeda, maka peneliti harus dapat menjelaskan perbedaan itu, tujuannya adalah untuk mencari kesamaan data dengan metode yang berbeda.

4. Triangulasi dengan Teori

Dilakukan

dengan menguraikan pola, hubungan dan menyertakan penjelasan yang muncul dari analisis untuk mencari tema atau penjelasan pembanding.

Dengan demikian dalam penelitian kualitatif ini teknik keabsahan data dilakukan dengan triangulasi sumber data yaitu dengan mengumpulkan informasi dari hasil tes dan wawancara.

Menurut Sugiyono (2007: 244) berpendapat bahwa analisis data adalah proses mencari dan menyusun secara sistematis data yang diperoleh dari hasil wawancara, catatan lapangan, dan dokumentasi, dengan cara mengorganisasikan data ke dalam kategori, menjabarkan ke dalam unitunit, melakukan sintesa, menyusun ke dalam pola, memilih mana yang penting dan yang akan dipelajari, dan membuat kesimpulan sehingga mudah dipahami oleh diri sendiri maupun orang lain.

Joko Subagyo (2004: 104) analisis dalam penelitian merupakan bagian dalam proses yang sangat penting karena dengan analisis inilah data yang ada akan nampak manfaatnya terutama dalam memecahkan masalah penelitian dan mencapai tujuan akhir penelitian.

Dalam proses analisis terdapat tiga komponen utama yang digunakan, tiga komponen utama tersebut adalah reduksi data, sajian data, dan penarikan kesimpulan serta verifikasinya. Berdasarkan analisis data kualitatif yang digunakan adalah reduksi data, kategorisasi dan sintesisasi.

\section{HASIL DAN PEMBAHASAN}

Penelitian ini menghasilkan data tentang profil kreativitas terhadap hasil belajar subyek dalam memecahkan Gemetri pada materi sistem koordinat ruang. Tes tulis dan wawancara ini dilakukan terhadap 6 orang mahasiswa yang dibagi dalam tiga kategori yaitu, 2 orang mahasiswa dengan kategori kemampuan tinggi, 2 orang mahasiswa dengan kategori kemampuan sedang, dan 2 orang mahasiswa dengan kategori kemampuan rendah sehingga memperoleh data yang valid tentang kreativitas mahasiswa.

\section{$\underline{\text { Analisis hasil Tes Tulis }}$}

\section{$\underline{\text { Subyek } 1}$}

Berdasarkan lembar kerja subyek 1 dalam menyelesaikan tes uraian 
dianalisis sebagai berikut:

a. Subyek mampu memahami masalah dengan baik yaitu subyek mampu mengetahui apa yang ditanyakan dalam soal dan dapat merencanakan strategi penyelesaian dengan tepat.

b. Subyek mampu menyelesaikan masalah sesuai dengan strategi penyelesaian dengan menggunakan prosedur yang benar.

c. Subyek mampu memahami masalah dengan baik yaitu subyek mampu mengetahui apa yang ditanyakan dalam soal dan dapat merencanakan strategi penyelesaian dengan tepat.

\section{Subyek 2}

Hasil analisis subyek 2 sesuai lembar kerja adalah :

a. Subyek mampu memahami masalah dengan baik yaitu subyek mampu mengetahui apa yang ditanyakan dalam soal dan dapat merencanakan strategi penyelesaian dengan tepat.

b. Subyek mampu menyelesaikan masalah sesuai dengan strategi penyelesaian dengan menggunakan prosedur yang benar.

c. Subyek terlihat sudah mampu menyelesaikan masalah sesuai dengan strategi penyelesaian dengan menggunakan prosedur yang benar.

\section{Subyek 3}

Peneliti menganalisis subyek berdasarkan lembar kerja adalah sebagai berikut:

a. Subyek mampu memahami masalah dengan baik yaitu mengetahui apa yang ditanyakan dalam soal dan perencanaan strateginya cenderung mengarah kejawaban yang benar.

b. Subyek mampu menyelesaikan masalah sesuai dengan strategi penyelesaian dengan menggunakan menggunakan prosedur yang benar.

c. Subyek mampu menentukan cara yang perlu dilakukan, cukup mampu memutuskan strategi yang cocok untuk diterapkan dalam menyelesaikan masalah sesuai yang diketahui dan yang ditanyakan dalam soal.

\section{Subyek 4}

Peneliti menganalisis subyek pada berdasarkan lembar kerja adalah sebagai berikut:

a. Subyek mampu memahami masalah dengan cukup baik yaitu mengetahui apa yang ditanyakan dalam soal dan perencanaan strateginya cenderung mengarah kejawaban yang benar.

b. Subyek terlihat sudah mampu menyelesaikan masalah sesuai dengan strategi penyelesaian dengan menggunakan menggunakan prosedur yang benar. 
c. Subyek mampu memahami masalah dengan cukup baik yaitu subyek mampu mengetahui apa yang ditanyakan dalam soal dan dapat merencanakan strategi penyelesaian dengan tepat.

d. Subyek mampu menentukan cara yang perlu dilakukan, cukup mampu memutuskan strategi yang cocok untuk diterapkan dalam menyelesaikan masalah sesuai yang diketahui dan yang ditanyakan dalam soal.

e. Subyek mampu memahami masalah dengan cukup baik yaitu subyek mampu mengetahui apa yang ditanyakan dalam soal dan dapat merencanakan strategi penyelesaian dengan tepat.

$\underline{\text { Subyek } 5}$

Peneliti menganalisis subyek 5 berdasarkan lembar kerja adalah sebagai berikut:

a. Subyek mampu memahami masalah dengan baik yaitu mengetahui apa yang ditanyakan dalam soal.

b. Subyek mampu menentukan strategi dalam menyelesaikan masalah. Subyek paham apa yang diketahui dalam soal sehingga dalam menyelesaikan menggunakan cara yang dibuat sendiri dan jawabannya salah c. Subyek mampu memahami masalah dengan cukup baik yaitu subyek mampu mengetahui apa yang ditanyakan dalam soal dan dapat merencanakan strategi penyelesaian dengan tepat.

\section{Subyek 6}

Peneliti menganalisis subyek pada berdasarkan lembar kerja adalah sebagai berikut:

a. Subyek tidak dapat menentukan strategi yang tepat untuk menyelesaikan masalah, sehingga subyek tersebut tidak dapat menyelesaikan masalah dengan tepat.

b. Subyek tidak mampu memahami masalah dengan baik yaitu mengetahui apa yang ditanyakan dalam soal tetapi perencanaan strateginya cenderung mengarah kejawaban yang salah.

c. Subyek tidak dapat menentukan strategi dalam menyelesaikan masalah. Subyek tidak paham apa yang diketahui dalam soal sehingga dalam menyelesaikan menggunakan cara yang dibuat sendiri dan jawabannya salah.

Untuk lebih memahami ke enam subyek, peneliti membuat bagan 4.1 berdasarkan analisis tes subyek pertama hingga keenam. 
Tabel 1. Hasil Analisis Data Tes Uraian

\begin{tabular}{|c|c|c|c|c|c|c|c|c|}
\hline No & \multicolumn{10}{|c|}{ Deskriptor Kreativitas } \\
\hline$(1)$ & $(2)$ & $(3)$ & $(4)$ & $(5)$ & $(6)$ & $(7)$ & $(8)$ & $(9)$ \\
\hline 1 & A1a & - & B1a & - & - & D1a & D1b & - \\
\hline 2 & A1a & - & B1a & B1b & - & D1a & D1b & - \\
\hline 3 & A1a & - & - & B1b & - & D1a & D1b & - \\
\hline 4 & A1a & - & - & B1b & - & D1a & D1b & - \\
\hline 5 & A1a & - & - & - & B1c & - & D1b & D1c \\
\hline 6 & - & A1b & - & - & B1c & - & - & D1c \\
\hline
\end{tabular}

\section{Paparan Data Hasil Wawancara}

Pada penelitian ini metode wawancara digunakan untuk menganalisis dan memperkuat hasil tes, selanjutnya dalam wawancara ini subyek penelitian 6 orang subyek yang telah ditentukan. Tujuan kegiatan ini adalah untuk melengkapi informasi yang diperoleh dari hasil tes tulis. Dalam wawancara ini peneliti melakukan wawancara terbuka untuk mengetahui profil kreativitas subyek dalam memecahkan masalah. Berikut ini adalah cuplikan hasil wawancara yang telah dilakukan.

\section{Analisis wawancara}

\section{Subyek 1}

a. Subyek mampu mengetahui apa yang ditanyakan dalam soal dan dapat merencanakan strategi penyelesaian dengan tepat.

Kelancaran subyek dapat membuat lebih dari satu gagasan. b. Subyek mampu menyelesaikan masalah dengan lebih dari satu cara. Subyek hanya menggunakan pada operasi hitungnya saja, sehingga cara lain yang diberikan tetap menggunakan konsep keliling yang sama dengan yang pertama, tetapi dengan proses perhitungan yang berbeda.

c. Subyek mampu menggunakan konsep baru untuk menyelesaikan masalah. Subyek dapat menentukan rumus keliling persegi panjang dan dapat menentukan strategi penyelesaian dengan benar dan baru, meskipun hanya mengubah satuannya.

d. Subyek mampu menjawab soal dengan benar. Kerincian subyek dapat merinci gagasan pokok ke gagasan yang lebih kecil dengan tepat.

\section{Subyek 2}

a. Subyek mampu mengetahui apa yang ditanyakan dalam soal dan dapat merencanakan strategi penyelesaian dengan tepat. Kelancaran subyek dapat membuat lebih dari satu gagasan.

b. Subyek mampu menyelesaikan masalah dengan lebih dari satu cara. Meskipun cara lain yang digunakan subyek tersebut hanya pada operasi 
hitungnya saja, sehingga cara lain yang diberikan tetap menggunakan konsep keliling yang sama dengan yang pertama, tetapi dengan proses perhitungan yang berbeda.

c. Subyek mampu menggunakan konsep baru untuk menyelesaikan masalah. Subyek tidak dapat menentukan rumus keliling persegi panjang dan menentukan strategi penyelesaian dengan benar dan baru.

d. Subyek mampu menggunakan konsep baru untuk menyelesaikan masalah. Subyek dapat menentukan rumus keliling persegi panjang dan dapat menentukan strategi penyelesaian dengan benar tetapi jawaban yang dihasilkan tidak baru.

e. Subyek mampu menjawab soal dengan benar. Kerincian subyek dapat merinci gagasan pokok ke gagasan yang lebih kecil dengan tepat.

\section{$\underline{\text { Subyek } 3}$}

a. Subyek mampu mengetahui apa yang ditanyakan dalam soal dan dapat merencanakan strategi penyelesaian dengan tepat.

Kelancaran subyek dapat membuat lebih dari satu gagasan.

b. Subyek mampu menyelesaikan masalah dengan lebih dari satu cara. Meskipun cara lain yang digunakan subyek tersebut hanya pada operasi hitungnya saja, sehingga cara lain yang diberikan tetap menggunakan konsep keliling yang sama dengan yang pertama..

c. Subyek mampu menggunakan konsep baru untuk menyelesaikan masalah. Subyek tidak dapat menentukan rumus keliling persegi panjang dan menentukan strategi penyelesaian dengan benar dan baru.

d. Subyek mampu menjawab soal dengan benar. Kerincian subyek dapat merinci gagasan pokok ke gagasan yang lebih kecil dengan tepat.

Subyek 4

a. Subyek mampu mengetahui apa yang ditanyakan dalam soal dan dapat merencanakan strategi penyelesaian dengan tepat. Kelancaran subyek dapat membuat satu gagasan.

b. Subyek tidak mampu menyelesaikan masalah dengan satu cara. Sebenarnya subyek dapat menyelesaikan dengan benar tetapi kurang konsentrasi.

c. Subyek mampu menggunakan konsep baru untuk menyelesaikan masalah. Subyek tidak dapat menentukan rumus keliling persegi panjang dan menentukan strategi penyelesaian dengan benar dan baru. 
d. Subyek tidak mampu menjawab soal dengan benar. Kerincian subyek dapat merinci gagasan pokok ke gagasan yang lebih kecil dengan tepat..

\section{$\underline{\text { Subyek } 5}$}

a. Subyek mampu mengetahui apa yang ditanyakan dalam soal dan dapat merencanakan strategi penyelesaian dengan tepat.

Kelancaran subyek dapat membuat satu gagasan.

b. Subyek tidak mampu menyelesaikan masalah dengan satu cara. Sebenarnya subyek dapat menyelesaikan dengan benar tetapi kurang konsentrasi.

c. Subyek mampu menggunakan konsep baru untuk menyelesaikan masalah. Subyek tidak dapat menentukan rumus keliling persegi panjang dan menentukan strategi penyelesaian dengan benar dan baru.

d. Subyek tidak mampu menjawab soal dengan benar. Kerincian subyek dapat merinci gagasan pokok ke gagasan yang lebih kecil dengan tepat. Sehingga pada unsur kerincian
Subyek 6

a. Subyek mampu mengetahui apa yang ditanyakan dalam soal dan dapat merencanakan strategi penyelesaian dengan tepat. Kelancaran subyek dapat membuat satu gagasan. Sehingga pada unsur kelancaran subyek 6 termasuk dalam kriteria cukup dan tergolong kode A1b.

b. Subyek tidak mampu menyelesaikan masalah dengan satu cara.

c. Subyek mampu menggunakan konsep baru untuk menyelesaikan masalah. Subyek tidak dapat menentukan rumus keliling persegi panjang dan menentukan strategi penyelesaian dengan benar dan baru.

d. Subyek tidak mampu menjawab soal dengan benar. Kerincian subyek dapat merinci gagasan pokok ke gagasan yang lebih kecil dengan tepat. Sehingga pada unsur kerincian subyek termasuk dalam kriteria kurang dan tergolong kode D1c.

Untuk lebih memperjelas dan memahami, peneliti membuat tabel 4.1 berdasarkan analisis data wawancara di atas. 
Tabel 2. Hasil Analisis Data Wawancara

\begin{tabular}{|c|c|c|c|c|c|c|c|c|c|c|}
\hline No & \multicolumn{10}{c|}{ Deskriptor Kreativitas } \\
\hline$(1)$ & $(3)$ & $(4)$ & $(5)$ & $(6)$ & $(7)$ & $(8)$ & $(9)$ & $(10)$ & $(11)$ & $(12)$ \\
\hline 1 & A1a & - & B1a & - & - & C1b & C1c & D1a & - & - \\
\hline 2 & A1a & - & B1a & - & - & C1b & C1c & D1a & - & - \\
\hline 3 & A1a & - & - & B1b & - & - & C1c & D1a & D1b & - \\
\hline 4 & A1a & - & - & B1b & - & - & C1c & - & D1b & - \\
\hline 5 & - & A1b & - & - & B1c & - & C1c & - & D1b & D1c \\
\hline 6 & - & A1b & - & - & B1c & - & C1c & - & D1b & D1c \\
\hline
\end{tabular}

\section{KESIMPULAN}

Berdasarkan tabel 4.1 hasil analisis data wawancara, peneliti membuat tabel 4.2 sebagai berikut:

Tabel 3 .Kode Kreativitas Siswa Dari Hasil Tes Tulis Dan Wawancara

\begin{tabular}{|c|c|c|c|c|}
\hline No. & \multicolumn{4}{|c|}{ Deskriptor Kreativitas } \\
\hline$(1)$ & $(2)$ & $(3)$ & $(4)$ & $(5)$ \\
\hline 1 & A1a & B1a & C1c & D1a \\
\hline 2 & A1a & B1a & C1c & D1a \\
\hline 3 & A1a & B1b & C1c & D1a \\
\hline 4 & A1a & B1b & C1c & D1b \\
\hline 5 & A1b & B1c & C1c & D1b \\
\hline 6 & A1b & B1c & C1c & D1b \\
\hline
\end{tabular}

Pada penelitian ini ditemukan subyek yang mempunyai dua kode (tidak mungkin), berarti harus ditindak lanjuti dengan memilih satu kode yang lebih dominan dapat mempengaruhi profil kreativitas siswa terhadap hasil belajar.
Berdasarkan analisis data dan pembahasan serta mengacu pada tujuan penelitian maka dapat diambil kesimpulan sebagai berikut:

$$
\text { Kedua mahasiswa kriteria }
$$
kemampuan tinggi menunjukkan bahwa berkecenderungan untuk memiliki profil kreativitas terhadap hasil belajar siswa yang baik dalam memecahkan masalah Geometri pada materi sistem koordinat ruang. Siswa mampu menyelesaikan masalah dengan lebih dari satu cara dan tepat.

Kedua mahasiswa kriteria kemampuan sedang menunjukkan bahwa berkecenderungan untuk memiliki profil kreativitas terhadap hasil belajar siswa yang cukup baik dalam memecahkan masalah Geometri pada materi sistem koordinat ruang.a. Secara umum siswa tersebut mampu menyelesaikan masalah dengan satu 
cara. Siswa kriteria sedang ini jika diberikan sedikit bimbingan dengan baik maka akan cenderung memiliki profil kreativitas yang baik.

Kedua mahasiswa kriteria kemampuan rendah menunjukkan bahwa berkecenderungan untuk memiliki profil kretivitas yang kurang baik dalam memecahkan masalah Geometri pada materi sistem koordinat ruang. Secara umum siswa tersebut tidak mampu menyelesaikan masalah sesuai dengan strategi penyelesaian yang benar.

Berdasarkan simpulan di atas bahwa kreativitas mahasiswa dalam menyelesaikan masalah yang berkaitan dengan Geometri pada materi sistem koordinat ruang ataupun dalam menyelesaikan permasalahan matematika tidak hanya bisa dilihat ataupun sekedar diukur dengan hasil belajar saat ujian akhir saja, karena kenyataan yang ada di lapangan mahasiswa dengan hasil belajar dikelas dengan kategori tinggipun belum tentu semua mahasiswa tersebut juga memiliki kreativitas yang unggul pula, dan sebaliknya.

\section{DAFTAR PUSTAKA}

Anas Sudijono. 2009. Pengantar Evaluasi Pendidikan.Jakarta: PT Raja Grafindo Persada
Budi Wahyono. 2012. Kreativitas Siswa. (online).

(http://www.pendidikanekonom i.com, diunduh 22 Maret 2013)

Burhan Bungin. 2007. Penelitian Kualitatif Komunikasi, Ekonomi, Kebijakan Publik, dan Ilmu Sosial. Jakarta: Prenada Media Group.

Djama'an \& Riduwan. 2011. Metodologi Penelitian Kualitatif. Bandung: Alfabeta.

Emzir. 2011. Metodologi Penelitian Kualitatif Analisis Data. Jakarta: PT Raja Grafindo Persada

Hamzah B. Uno. 2007. Model Pembelajaran Menciptakan Proses Belajar yang Kreatif dan Efektif. Jakarta: PT Bumi Aksara

Herman Hudojo. 2005. Pengembangan Kurikulum Dan Pembelajaran Matematika. Malang: IKIP Malang

IKIP PGRI MADIUN. 2013. PedomanPenulisanSkripsiEd isi 2013. Madiun: Institut Press.

Joko Subagyo. 2004. Metode Penelitian Dalam Teori dan Praktek. Jakarta: PT Rineka Cipta.

Nana Sudjana. 2011. Penilaian Hasil Proses Belajar Mengajar. 
Bandung: Remaja
Rosdakarya.

Purwanto. 2011. Evaluasi Hasil Belajar.

Yogyakarta: Pustaka Belajar

Santrock, W John. 2009. Psikologi

Pendidikan Educational

Psychology Edisi Ke 3.

Jakarta: Salemba Humanika.

Slameto. 2010. Belajar dan Faktor-

Faktor yang

Mempengaruhinya. Jakarta:

Rineka Cipta.

Sugiyono. 2007. Metode Penelitian

Kuantitatif Kualitatif dan $R$ \&

$D$. Bandung: Alfabeta.

Suharsimi Arikunto. 2012. Dasar-Dasar

Evaluasi Pendidikan Edisi 2.

Jakarta: Bumi Aksara.

Sukardjono dan Edy Purwanto (Ed.).

2007. Hakikat dan Sejarah

Matematika. Jakarta:

Universitas Terbuka.

Uhar Suharsaputra. 2012. Metode

Penelitian Kuantitatif,

Kualitatif, dan Tindakan.

Bandung: Refika Aditama.

Utami Munandar. 2004. Pengembangan

Kreativitas Anak Berbakat.

Jakarta: PT Rineka Cipta

Wasilatul, Murtafiah. 2009. Jurnal Pendidikan Matematika (Volume 1, Nomor 2). Madiun: IKIP PGRI MADIUN.

Yeni dan Euis. 2010. Strategi
Pengembangan Kreativitas

pada Anak. Jakarta: Prenada

Media Group 